\title{
Heat Tolerance and Flowering-heat-delay Sensitivity in Relation to Cell Membrane Thermostability in Chrysanthemum
}

\author{
Ching-Hsueh Wang and Der-Ming Yeh ${ }^{1}$ \\ Department of Horticulture, National Taiwan University, No. 1, Roosevelt Road Section 4, Taipei, \\ 106, Taiwan \\ Chian-Shinn Sheu \\ Taichung District Agricultural Research and Extension Station, 370, Song Hwai Road, Tatsuen \\ Hsiang, Chnaghua, 51501, Taiwan
}

\begin{abstract}
AdDitional INDEX wORDs. cultivar, Dendranthema $\times$ grandiflora, acclimation, malondialdehyde, relative injury
ABSTRACT. Flowering of many chrysanthemum [Dendranthema $\times$ grandiflora (Ramat.) Kitam.] cultivars is reduced or delayed under high temperatures. Identification and rapid selection of heat-tolerant and flowering-heat-delayinsensitive chrysanthemum genotypes for commercial production is desirable. An electrolyte leakage technique was used to measure cell membrane thermostability of chrysanthemum cultivars. The relationship between the relative injury (RI) value occurring in leaf tissue discs and the treatment temperature was sigmoidal. The RI values at the approximate midpoint of the sigmoid response curve occurred at 47 to $53{ }^{\circ} \mathrm{C}$ for summer- and fall-flowering cultivars and at 45 to $46{ }^{\circ} \mathrm{C}$ treatments for winter- and spring-flowering cultivars. Regressing the delay in days to flowering for the cultivars grown at day/night temperature of $30 / 25^{\circ} \mathrm{C}$ compared with those grown at $20 / 15^{\circ} \mathrm{C}$ versus their associated RI values at $50{ }^{\circ} \mathrm{C}$ treatment showed a linear relationship. Reduced RI was more apparent in the heattolerant 'Kaa Luoh-Lii' than the heat-intolerant 'Repulse' after $30 / 25^{\circ} \mathrm{C}$ treatment for 24 to 27 days. When $30 / 25$ and $20 / 15^{\circ} \mathrm{C}$ treatments were compared, the former did not alter leaf malondialdehyde (MDA) content in 'Kaa Luoh-Lii' but increased MDA content in 'Repulse'.
\end{abstract}

For year-round production, growers in the subtropical areas conventionally divide chrysanthemum cultivars or lines into two groups: heat-tolerant (flowering during the natural summer and fall seasons) and heat-intolerant (flowering during the natural winter and spring seasons). In chrysanthemum, delayed anthesis is induced by temperatures of 26 to $32{ }^{\circ} \mathrm{C}$ (Karlsson et al., 1989; Whealy et al., 1987). Breeding heat-tolerant or heat-delay-insensitive genotypes is vital because the summer temperature is high whether in greenhouses or in the field. Shibata and Kawata (1987) measured differences in the degree of heat delay among Japanese chrysanthemum cultivars by growing the plants to flower in the summer; and they found that some genotypes may carry heat tolerance genes. Heat-delayinsensitive chrysanthemum genotypes exist, but screening for the desired seedlings by greenhouse or field evaluation techniques is slow (Anderson and Ascher, 2001; De Jong, 1989).

Cell membrane thermostability (CMT), measured as electrolyte leakage from leaf discs over a range of temperatures, is a sensitive and rapid method to evaluate heat tolerance in plants (Sullivan, 1972; Wu and Wallner, 1983). Several studies have shown the effectiveness of CMT testing in detecting genetic variability for heat tolerance among several crops (Chen et al., 1982; Lester, 1985; Martineau et al., 1979; Saadalla et al., 1990; Sullivan and Ross, 1979; Yeh and Hsu, 2004). Our previous report showed that, for summer- and fall-flowering chrysanthemum cultivars, those having a low relative injury value coincide with the greater CMT and shorter heat-induced delay to flowering in field conditions (Yeh and Lin, 2003). Little

Received for publication 22 July 2008. Accepted for publication 26 Sept. 2008 ${ }^{1}$ Corresponding author. E-mail: dmyeh@ntu.edu.tw. information on CMT in winter- and spring-flowering chrysanthemums is available at present.

Karlsson et al. (1989) reported that optimum temperatures in the growing periods from 1) start of short days to visible bud; 2) visible bud to disbud; 3) disbud to flower color; or 4) flower color to harvest were $21.3,20.3,23.1$, and $19.1{ }^{\circ} \mathrm{C}$, respectively, for chrysanthemums. However, they did not determine the difference in temperature effects on developmental phases in chrysanthemum cultivars with different heat tolerance or flowering-heat-delay sensitivity. Heat acclimation is required for detecting differences in heat tolerance among the lines or cultivars (Senthil-Kumar et al., 2003, 2007). Malondialdehyde (MDA) is a product of peroxidation of unsaturated fatty acids in phospholipids and is responsible for cell membrane damage (Halliwell and Gutteridge, 1989). It is hypothesized that heattolerant chrysanthemum cultivars would exhibit a greater adaptation to high growing temperatures and, hence, would have lower relative injury (RI) as well as MDA.

The objectives of this study were to 1) determine CMT of cultivars that flower in hot or cool seasons; 2) determine the effects of high temperature on the floral developmental phase in cultivars with different heat tolerance; and 3) compare RI and MDA of heat-tolerant versus heat-intolerant cultivars after heat treatment.

\section{Materials and Methods}

Stock Plants. On 2 Aug. 2003, rooted tip cuttings of 10 commercial chrysanthemum cultivars were planted in $16-\mathrm{cm}$ diameter plastic pots each containing sphagnum peat (Fafard No. 1; Conrad Fafard, Agawam, MA), perlite, and vermiculite mixed in equal volumes. To encourage later growth, shoot tips 
were pinched off 1 week after planting, leaving six leaves on each shoot. The plants were kept in a greenhouse at a mean daily temperature of $27{ }^{\circ} \mathrm{C}$ under 11.5 - to 12 -h natural daylength. Vegetative growth was maintained by a night break from 2200 to $0200 \mathrm{HR}$ using incandescent lamps giving $2.2 \mu \mathrm{mol} \cdot \mathrm{m}^{-2} \cdot \mathrm{s}^{-1}$ photosynthetic active radiation $[P A R(400$ to $700 \mathrm{~nm})$ ] at plant level. The plants were fertilized weekly with water-soluble $20.0 \mathrm{~N}-4.4 \mathrm{P}-24.9 \mathrm{~K}$ (Scotts, Marysville, OH) at $300 \mathrm{mg} \cdot \mathrm{L}^{-1}$ nitrogen.

LEAF CELL MEMBRANE THERMOSTABILITY MEASUREMENT FOR DIFFERENT CULTIVARS. On 24 Oct. 2003, fully expanded leaves (leaves three to six from apex) were harvested from stock plants of six summer- and fall-flowering cultivars (Fig. 1) and four winter- and spring-flowering cultivars (Fig. 2). These leaves were evaluated for CMT following procedures described by Yeh and Lin (2003). CMT was measured at 25, 30, 35, 40, 45, $50,55,60,65$, and $70{ }^{\circ} \mathrm{C}$ for $30 \mathrm{~min}$.

Each sample for assay consisted of five 6-mm diameter leaf discs (1.5 $\pm 0.3 \mathrm{mg}$ dry weight) cut from a group of five leaves with a cork borer. Before assay, the leaf discs were rinsed thoroughly with three rapid changes of distilled water. Leaf discs were then placed in $25 \times 150$-mm test tubes containing

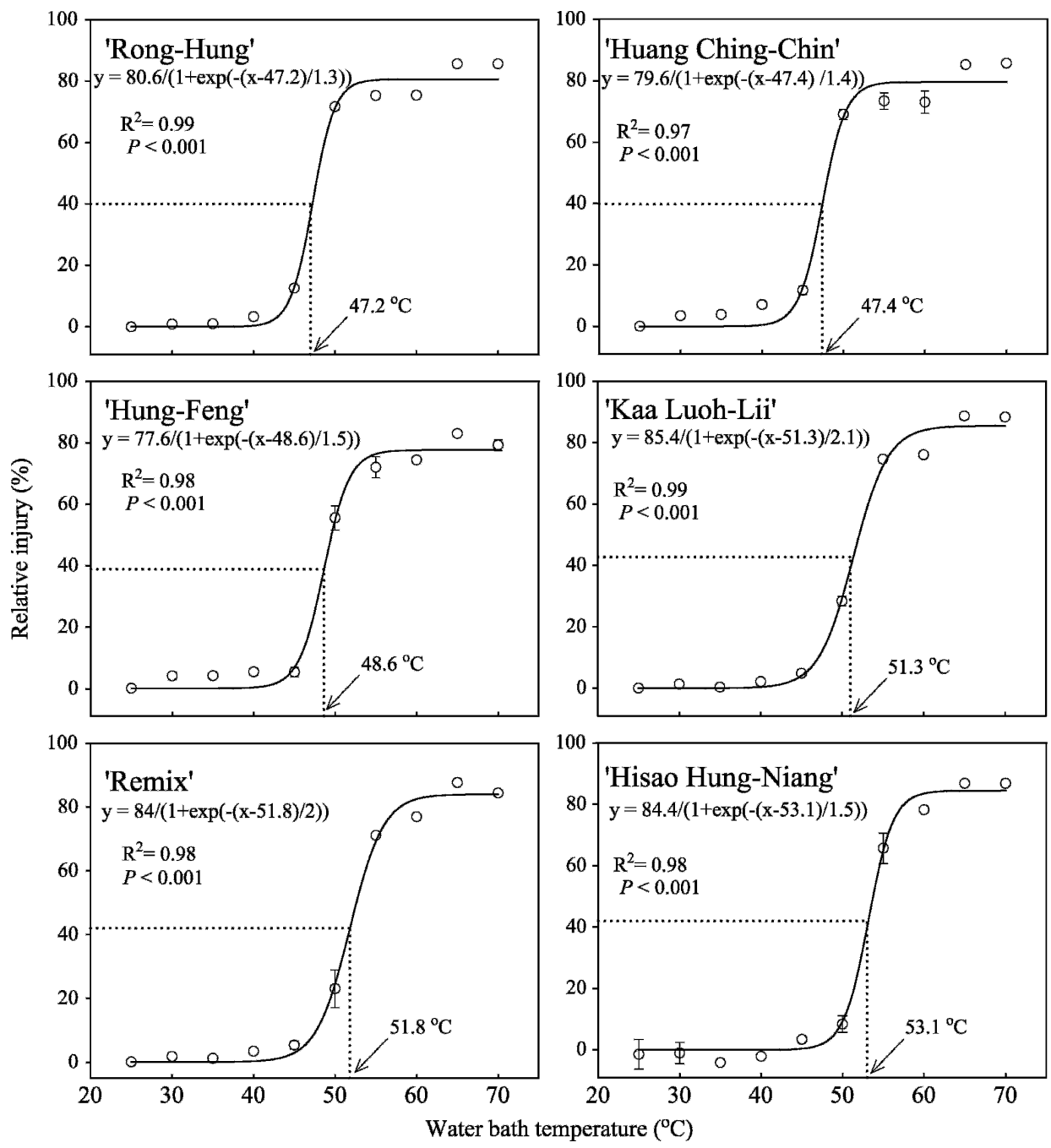

Fig. 1. Effect of water bath temperature on relative injury of leaves in summer- and fall-flowering chrysanthemum cultivars. Bars represent the SE and are not visible if smaller than the symbol.
$1 \mathrm{~mL}$ distilled water to prevent secondary water stress. Three tubes per treatment were placed in a heated, circulating water bath for $30 \mathrm{~min}$ at each treatment temperature. Distilled water $(16 \mathrm{~mL})$ was added to each tube after elevated temperature exposure. Samples were then placed at $10 \pm 2{ }^{\circ} \mathrm{C}$ for $24 \mathrm{~h}$ before solution conductivity was measured with a conductivity meter (model SC-170; Suntex Instruments, Taipei, Taiwan). The tubes were capped with foil, autoclaved $\left(121{ }^{\circ} \mathrm{C}, 1.2 \mathrm{~kg} \cdot \mathrm{cm}^{-2}\right)$ for $15 \mathrm{~min}$, cooled to $25^{\circ} \mathrm{C}$, and incubated for an additional $24 \mathrm{~h}$ before final conductivity measurements were taken. The degree of RI induced by the temperature treatment was calculated as follows: RI $(\%)=\left\{1-\left[1-\left(T_{1} / T_{2}\right)\right] /\left[1-\left(C_{1} / C_{2}\right)\right]\right\} \times 100$, where $T$ and $C$ refer to conductivity values for treatment and control $\left(25^{\circ} \mathrm{C}\right)$ vials, respectively, and subscripts 1 and 2 refer to initial and final conductivity readings, respectively. The relationship between RI value and water bath temperature treatments was determined with regression analysis using Sigma Plot (version 8.0; SPSS Inc., Chicago, IL). The inflection point, which is the midpoint of the sigmoid response curve, was calculated from the regression equation for each cultivar.

EFFECT OF TEMPERATURE UNDER 12- TO 13.5-H DAYLENGTH ON FLORAL DEVELOPMENT. As a result of limited space, only five chrysanthemum cultivars (Table 1) were used. Rooted cuttings were obtained from the stock plants and planted in 16-cm diameter plastic pots. Medium and fertilizer application were the same as described previously. Plants with 18 to 20 fully expanded leaves were transferred on 8 Mar. 2004 to greenhouses under natural 12- to $13.5-\mathrm{h}$ daylength during the experiment. The day/night temperatures were $20 / 15$ and $30 / 25^{\circ} \mathrm{C}$ for two treatments as measured at the top of plant canopy and recorded every $30 \mathrm{~min}$ by using a copper/constantan thermocouple (type T; MingGuan, Instruments, Chang-Hua, Taiwan) attached to a data logger (DL2e; Delta-T, Cambridge, UK). The time elapsed from the beginning of temperature treatment to visible bud [VB (2-mm diameter terminal bud)], show color (first appearance of color on flower bud), and anthesis were recorded at 3-d intervals for $120 \mathrm{~d}$.

The experiment was arranged within temperature treatments in a completely randomized design with six replicate plants in each treatment and the data tested by analysis of variance. Means were separated by $t$ test at $P \leq 0.05$. The degree of heat delay was calculated following the method of Shibata and Kawata (1987) as the difference between days to flowering at $20 / 15$ and at $30 / 25^{\circ} \mathrm{C}$. Regression analysis was used to determine the relationship 


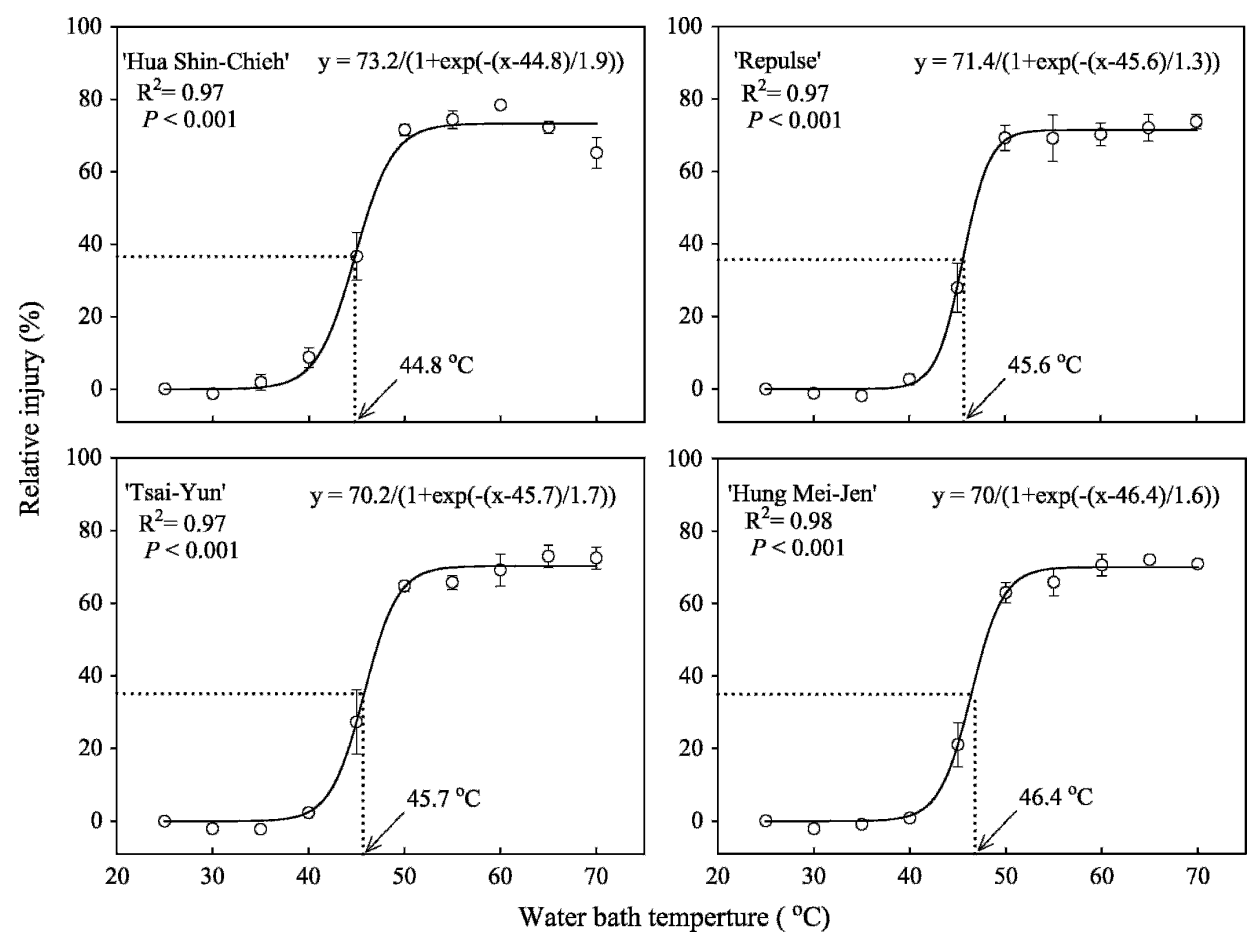

Fig. 2. Effect of water bath temperature on relative injury of leaves in winter- and spring-flowering chrysanthemum cultivars. Bars represent the SE and are not visible if smaller than the symbol.

Table 1. Effect of temperature on days to floral development stage of five chrysanthemum cultivars.

\begin{tabular}{lccr}
\hline & \multicolumn{3}{c}{ Time to development $(\mathrm{d})$} \\
\cline { 2 - 4 } Day/night temp $\left({ }^{\circ} \mathrm{C}\right)$ & Visible bud & Show color & Anthesis \\
\hline Hisao Hung-Niang & $39.3 \mathrm{a}^{\mathrm{z}}$ & $61.1 \mathrm{a}$ & $70.4 \mathrm{a}$ \\
$\quad 20 / 15$ & $41.8 \mathrm{a}$ & $66.7 \mathrm{a}$ & $75.4 \mathrm{a}$ \\
$\quad 30 / 25$ & $60.5 \mathrm{a}$ & $86.5 \mathrm{~b}$ & $92.2 \mathrm{~b}$ \\
Remix & $58.0 \mathrm{a}$ & $92.9 \mathrm{a}$ & $102.5 \mathrm{a}$ \\
$20 / 15$ & & & \\
$30 / 25$ & $45.8 \mathrm{a}$ & $63.6 \mathrm{~b}$ & $74.5 \mathrm{~b}$ \\
Hung-Feng & $47.3 \mathrm{a}$ & $82.3 \mathrm{a}$ & $89.6 \mathrm{a}$ \\
$20 / 15$ & & & \\
$30 / 25$ & $47.3 \mathrm{a}$ & $71.4 \mathrm{~b}$ & $80.2 \mathrm{~b}$ \\
Huang Ching-Chin & $43.0 \mathrm{a}$ & $98.0 \mathrm{a}$ & $112.3 \mathrm{a}$ \\
$20 / 15$ & & & \\
$30 / 25$ & 36.6 & 58.0 & 70.0 \\
Repulse & $-\mathrm{y}$ & - & - \\
$20 / 15$ & & & \\
$30 / 25$ & & & \\
\hline
\end{tabular}

${ }^{\mathrm{z}}$ Mean separation within columns and cultivars by $t$ test at $P \leq 0.05$. yPlants did not flower within $120 \mathrm{~d}$.

between the cultivars' RI values and their associated degree of heat delay.

EFFECT OF TEMPERATURE UNDER 11- TO 12-H DAYLENGTH ON FLORAL DEVELOPMENT, LEAF RELATIVE INJURY, AND MALONDIALDEHYDE. Rooted cuttings of 'Kaa Luoh-Lii' and 'Repulse' were planted in $11-\mathrm{cm}$ diameter plastic pots on 15 Sept. 2007. After pinching, three axillary shoots were allowed to grow on each plant. Plants were initially kept in a greenhouse at a mean daily temperature of $27^{\circ} \mathrm{C}$ under 11 - to 12-h natural daylength. Vegetative growth was maintained by a night break from 2100 to $0300 \mathrm{HR}$ using incandescent lamps giving $2.2 \mu \mathrm{mol} \cdot \mathrm{m}^{-2} \cdot \mathrm{s}^{-1}$ PAR (400 to 700 $\mathrm{nm})$ at plant level. Plants with 12 to 15 fully expanded leaves were transferred on 4 Oct. 2007 to greenhouses at $20 / 15$ or $30 / 25{ }^{\circ} \mathrm{C}$ under natural 11- to 12-h daylength. Both greenhouses had an average noon photosynthetic photon flux of 700 $\mu \mathrm{mol} \cdot \mathrm{m}^{-2} \cdot \mathrm{s}^{-1}$ during the experiment. The experiment was arranged within temperature treatments in a completely randomized design with 30 replicate plants in each treatment. Leaf number below the terminal inflorescence and time required to complete VB, show color, and anthesis in each cultivar were determined. The lengths of time to reach each developmental phase for each cultivar were compared between two temperature treatments by $t$ test.

From Day 0 to 27 after the beginning of temperature treatments, a random sample of 20 fully expanded leaves from six plants per treatment was taken at 3-d intervals for measurements of CMT and MDA. CMT was determined by measuring electrolyte leakages of leaf discs after water bathing at 25 and $50^{\circ} \mathrm{C}$ for 30 min and RI values were calculated as described previously. MDA was measured by using the method of Heath and Packer (1968) with some modification. Samples of $0.1 \mathrm{~g}$ leaf tissue were homogenized with a mortar. A $1-\mathrm{mL}$ aliquot of enzyme solution was added to a tube containing $4 \mathrm{~mL}$ of $20 \%(\mathrm{v} / \mathrm{v})$ trichloroacetic acid and $0.5 \%(\mathrm{v} / \mathrm{v})$ thiobarbituric acid. The leaf tissue was added to the tube and the mixture was heated in a water bath at $95^{\circ} \mathrm{C}$ for $30 \mathrm{~min}$ and then quickly cooled in an ice bath followed by centrifugation at $10,000 \mathrm{~g}_{\mathrm{n}}$ for $10 \mathrm{~min}$. The absorbance of the supernatant at $532 \mathrm{~nm}$ was determined with a spectrophotometer (model U-2800A; Hitachi, Tokyo, Japan) and the nonspecific absorbance at $600 \mathrm{~nm}$ was also determined and subtracted. The MDA content was calculated by the extinction coefficient of $155 \mathrm{~mm}^{-1} \mathrm{~cm}^{-1}$ (Heath and Packer, 1968). RI and MDA values were presented as means \pm SE.

\section{Results}

LEAF CELL MEMBRANE THERMOSTABILITY OF DIFFERENT CULTIVARs. The relationship between the RI value of leaf tissue discs and the treatment temperature was sigmoidal for all six summer- and fall-flowering chrysanthemum cultivars (Fig. 1). The RI values near the midpoint of the sigmoid response curve occurred at 47 to $53{ }^{\circ} \mathrm{C}$ water bath temperature for summer- and fall-flowering cultivars. A single temperature treatment at $50{ }^{\circ} \mathrm{C}$ for $30 \mathrm{~min}$ resulted in $72 \%$ and $69 \% \mathrm{RI}$ in 'Rong-Hung' and 'Huang Ching-Chin', but only 23\% and 9\% RI in 'Remix' and 'Hisao Hung-Niang', respectively.

In winter- and spring-flowering cultivars, the relationship between the RI values of leaf tissue discs and treatment temperatures was also sigmoidal (Fig. 2). However, the RI of 
this group of cultivars peaked at the $50{ }^{\circ} \mathrm{C}$ treatment. The RI values near the midpoint of the sigmoid response curve occurred at 45 to $46{ }^{\circ} \mathrm{C}$ water bath temperature. These results suggest that differences in heat tolerance of leaf tissues exist between chrysanthemum cultivars and the differences are detectable by measuring CMT.

EFFECT OF TEMPERATURE UNDER 12- TO 13.5-H DAYLENGTH ON FLORAL DEVELOPMENT. Plants of 'Hisao Hung-Niang' flowered at the same time regardless of two different growing temperatures (Table 1). Plants of cultivars Remix, Hung-Feng, and Huang Ching-Chin took longer to anthesis at 30/25 than at $20 / 15^{\circ} \mathrm{C}$. The flowering-heat-delay was not the result of longer time required to attain visible bud stage, but attributable to slower bud development at $30 / 25{ }^{\circ} \mathrm{C}$. 'Repulse' failed to show reach visible bud stage in $120 \mathrm{~d}$ at $30 / 25^{\circ} \mathrm{C}$. 'Huang Ching-Chin', which had a relatively low temperature to attain the midpoint of the sigmoid response curve (Fig. 1), and a long delay to flowering under high temperatures (Table 1), looks more like a winter/spring cultivar than a summer cultivar.

RELATIONSHIP BETWEEN LEAF CELL MEMBRANE THERMOSTABILITY AND HEAT DELAY. Heat delay-sensitive cultivars had higher RI values at $50{ }^{\circ} \mathrm{C}$ water bath (Fig. 1) and a greater degree of heat delay at $30 / 25^{\circ} \mathrm{C}$ (Table 1). After a point for nonflowering in 'Repulse' at $30 / 25{ }^{\circ} \mathrm{C}$ (Table 1) was omitted, regressing the delay in days to flowering for planting at $30 / 25{ }^{\circ} \mathrm{C}$ versus their associated $\mathrm{RI}$ values at $50{ }^{\circ} \mathrm{C}$ water bath treatment in the cultivars showed a linear relationship (Fig. 3).

EFFECT OF TEMPERATURE UNDER 11- TO 12-H DAYLENGTH ON FLORAL DEVELOPMENT, LEAF RELATIVE INJURY, AND MALONDIALDEHYDE. Temperature treatments did not alter leaf number below the inflorescence, days to show color, and anthesis in 'Kaa Luoh-Lii' (Table 2). In contrast, plants of 'Repulse' had more leaves below the inflorescence and took longer to reach $\mathrm{VB}$, show color, and anthesis at 30/25 than at $20 / 15^{\circ} \mathrm{C}$.

During the first $6 \mathrm{~d}$ after the start of $20 / 15$ versus $30 / 25^{\circ} \mathrm{C}$ temperature treatments, RI increased for both cultivars (Fig. $4 \mathrm{~A}-\mathrm{B})$. From Day 6 to 27, the response of leaf RI to growing temperature differed between cultivars. Leaf RI of 'Kaa LuohLii' declined from $90 \%$ to $70 \%$ at $20 / 15{ }^{\circ} \mathrm{C}$ and from $80 \%$ to $40 \%$ at $30 / 25^{\circ} \mathrm{C}$. RI of 'Repulse' ranged between $85 \%$ and $90 \%$ at $20 / 15{ }^{\circ} \mathrm{C}$ but decreased from $90 \%$ to $70 \%$ at $30 / 25{ }^{\circ} \mathrm{C}$. Reduced RI was more apparent in 'Kaa Luoh-Lii' than 'Repulse' after $30 / 25{ }^{\circ} \mathrm{C}$ treatment for $\approx 24$ to $27 \mathrm{~d}$.

Leaf MDA content declined during the first $6 \mathrm{~d}$ after the start of temperature treatments for both cultivars (Fig. 4C-D). Leaf MDA content of 'Kaa Luoh-Lii' increased thereafter and ranged between 50 and $60 \mathrm{nmol} \cdot \mathrm{g}^{-1}$ fresh weight in both temperature treatments. Leaf MDA of 'Repulse' also decreased in the first $6 \mathrm{~d}$; and MDA at $30 / 25^{\circ} \mathrm{C}$ was consistently higher than that at $20 / 15^{\circ} \mathrm{C}$ only after $12 \mathrm{~d}$ (Fig. 4D).

\section{Discussion}

The electrolyte leakage test is one of the most convenient methods of screening crops for heat tolerance (Martineau et al., 1979; Sullivan, 1972). The present study with chrysanthemum showed electrolyte leakage from leaf discs to have a sigmoidal response to increasing temperature (Figs. 1 and 2). Similar response curves have been reported for a number of agronomic crops (Chen et al., 1982; Ismail and Hall, 1999), fruit crops

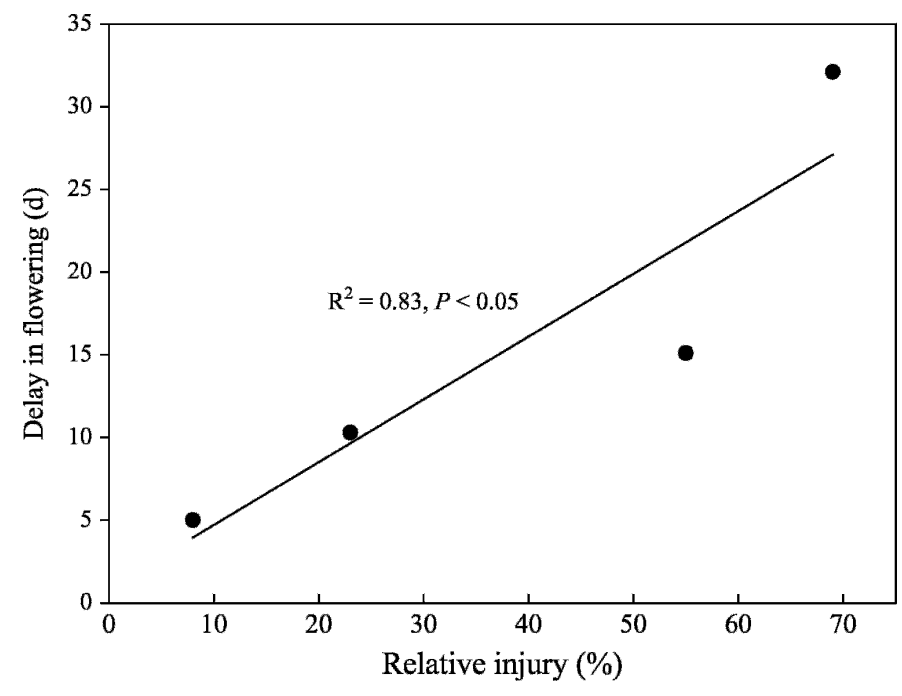

Fig. 3. Relationship between flowering delay and relative injury of chrysanthemum cultivars. The degree of heat delay was calculated as the difference between days to flowering in plants grown at $20 / 15$ and $30 / 25^{\circ} \mathrm{C}$.

Table 2. Effect of temperature on leaf number below the inflorescence and floral development in chrysanthemum cultivars Kaa Luoh-Lii and Repulse.

\begin{tabular}{|c|c|c|c|c|}
\hline \multirow[b]{2}{*}{$\begin{array}{l}\text { Day/night } \\
\text { temp }\left({ }^{\circ} \mathrm{C}\right)\end{array}$} & \multirow{2}{*}{$\begin{array}{c}\text { Leaves below } \\
\text { inflorescence } \\
\text { (no.) }\end{array}$} & \multicolumn{3}{|c|}{ Time to development (d) } \\
\hline & & $\begin{array}{c}\text { Visible } \\
\text { bud }\end{array}$ & $\begin{array}{l}\text { Show } \\
\text { color }\end{array}$ & Anthesis \\
\hline \multicolumn{5}{|c|}{ Kaa Luoh-Lii } \\
\hline $20 / 15$ & $37.3 \mathrm{a}^{\mathrm{z}}$ & $26.3 \mathrm{a}$ & $56.1 \mathrm{a}$ & $62.3 \mathrm{a}$ \\
\hline $30 / 25$ & $38.0 \mathrm{a}$ & $24.3 \mathrm{~b}$ & $54.3 \mathrm{a}$ & $61.1 \mathrm{a}$ \\
\hline \multicolumn{5}{|l|}{ Repulse } \\
\hline $20 / 15$ & $37.5 \mathrm{~b}$ & $21.0 \mathrm{~b}$ & $48.1 \mathrm{~b}$ & $54.0 \mathrm{~b}$ \\
\hline $30 / 25$ & $40.7 \mathrm{a}$ & $26.1 \mathrm{a}$ & $63.5 \mathrm{a}$ & $70.5 \mathrm{a}$ \\
\hline
\end{tabular}

${ }^{\mathrm{z}}$ Mean separation within columns and cultivars by $t$ test at $P \leq 0.05$.

(Ingram and Buchanan, 1984), vegetable crops (Inaba and Crandall, 1988; Lester, 1985), and ornamentals (Yeh and Hsu, 2004; Yeh and Lin, 2003).

It would be tedious to derive injury response curves such as shown in Figures 1 and 2 for a lot of individual plants. From a practical perspective, it is easier to set up a single temperature bath for electrolyte test than to set up many different temperatures. The $50{ }^{\circ} \mathrm{C}$ water bath treatment followed by $\mathrm{RI}$ assessment resulted in the best differentiation between heat tolerance for summer cultivars (Fig. 1) but resulted in plateaued RI values for winter cultivars (Fig. 2). The present results agree with Yeh and Lin (2003) who showed that a single temperature treatment at $50{ }^{\circ} \mathrm{C}$ generated the greatest sensitivity in detecting genotypic differences in heat tolerance. CMT technique may be useful for growers to evaluate the heat tolerance of new cultivars or lines before scheduling commercial production and marketing. The present study and our previous results (Yeh and Lin, 2003) indicated that cultivars with leaf RI greater than $70 \%$ after a $50{ }^{\circ} \mathrm{C}$ water bath treatment for $30 \mathrm{~min}$ are not suitable for hot summer season production as a result of excessive flowering heat delay.

A positive linear relationship was found between leaf RI value and the degree of heat-induced flowering delay in chrysanthemums (Fig. 3). Thermotolerance being correlated 


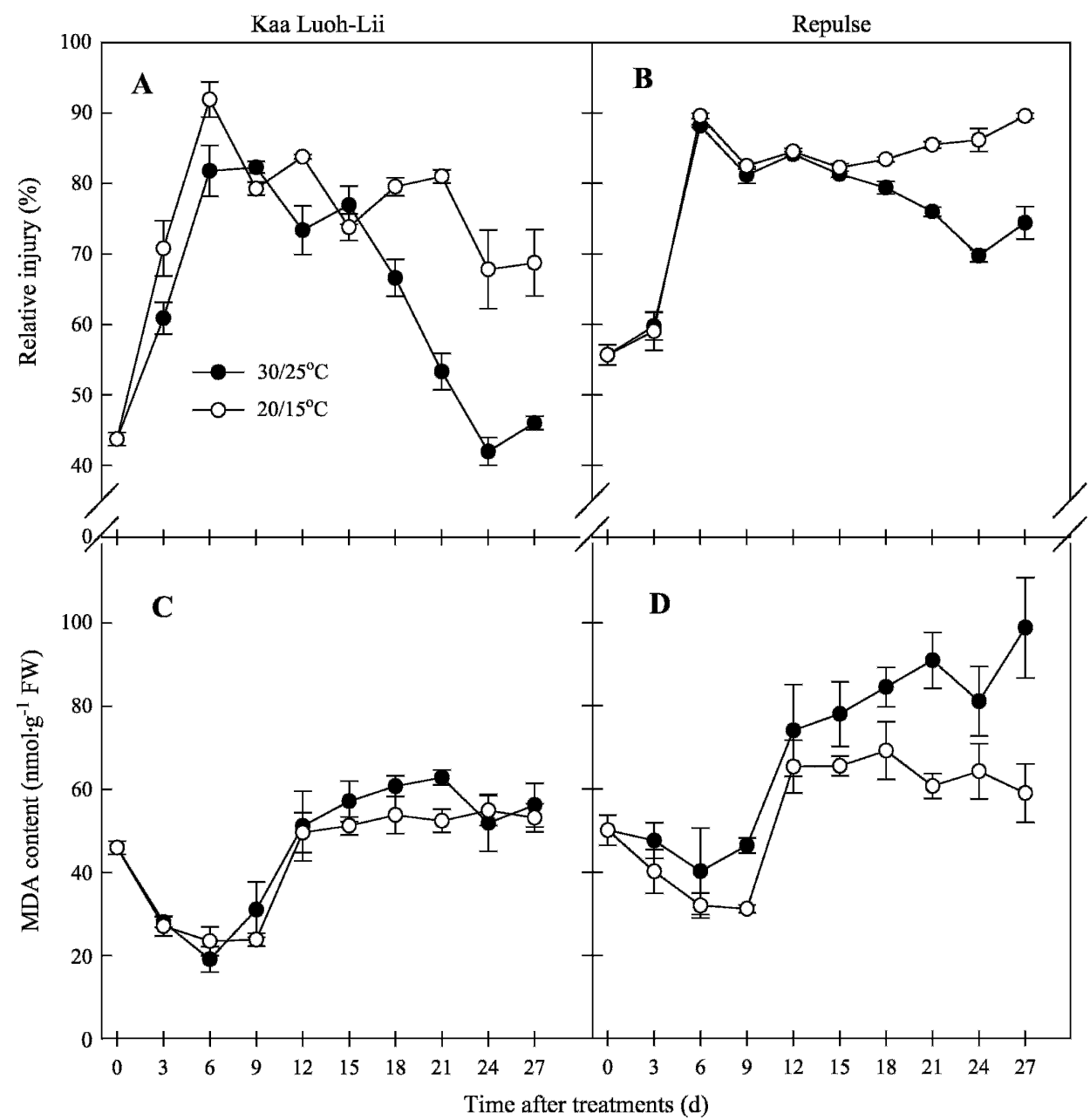

Fig. 4. Changes in relative injury and malondialdehyde (MDA) content of leaves in chrysanthemum cultivars Kaa Luoh-Lii and Repulse at $20 / 15$ and $30 / 25^{\circ} \mathrm{C}$. Bars represent the SE.

between the young vegetative and flowering stages has been reported among spring wheat (Triticum aestivum L.) cultivars (Fokar et al., 1998), winter wheat genotypes (Saadalla et al., 1990), and cowpea [Vigna unguiculata (L.) Walp.] (Ismail and Hall, 1999). Measurement of leaf CMT is simple, quick, and less expensive than a whole-plant screening $(\mathrm{Wu}$ and Wallner, 1983). Therefore, breeders can use the CMT technique to screen large populations of plants for their heat tolerance at their early stage of development.

The cultivar Hisao Hung-Niang appeared to be heat-delayinsensitive (Table 1), indicating the potential use for the introduction of its heat tolerance genes to new cultivars (Shibata and Kawata, 1987). Delayed anthesis occurred with the cultivars Remix, Hung-Feng, and Huang Ching-Chin at $30 / 25^{\circ} \mathrm{C}$ (Table 1). Delayed anthesis of chrysanthemums with temperatures of 26 to $32{ }^{\circ} \mathrm{C}$ have been reported previously (Cockshull, 1979; Karlsson et al., 1989; Whealy et al., 1987). High temperatures that result in heat delay vary across ornamental species and/or cultivars. For example, Schlumbergera truncate (Haw.) Moran flower initiation was inhibited when average daily temperature reached $<25^{\circ} \mathrm{C}$ (Erwin et al., 1990). Increasing temperature from 20 to $30^{\circ} \mathrm{C}$ increased days to flowering of 12 Viola $\times$ wittrockiana Gams. cultivars (Warner and Erwin, 2006). Delayed anthesis in the cultivars Remix, Hung-Feng, and Huang Ching-Chin was attributed to delayed flower development after visible bud phase rather than to delayed flower initiation (Table 1). A similar heat delay of flower development has been reported for other chrysanthemum cultivars (Karlsson et al., 1989; Whealy et al., 1987).

Regardless of temperature treatments, plants of 'Kaa Luoh-Lii' had similar leaf number below the terminal inflorescence and days to anthesis (Table 2). In contrast, plants of 'Repulse' had more leaves below the inflorescence and took longer to anthesis at $30 / 25$ than at $20 / 15^{\circ} \mathrm{C}$. These are consistent with previous results that cultivars with a lower leaf RI at the $50^{\circ} \mathrm{C}$ treatment had no or shorter heat-induced delay to flowering (Figs. 1-3). Plants of 'Repulse' at $20 / 15{ }^{\circ} \mathrm{C}$ flowered earlier under 11.5 to $12 \mathrm{~h}$ than 12 - to 13.5-h daylength (Tables 1 and 2), indicating a quantitative short-day plant for flowering. In the $30 / 25^{\circ} \mathrm{C}$ treatment, 'Repulse' did not initiate flower buds under 12- to 13.5 -h daylength after $120 \mathrm{~d}$, but the plants flowered under 11.5- to 12-h daylength after $70 \mathrm{~d}$ (Tables 1 and 2). Cathey (1957) noted that high temperature has a great influence on critical daylength on flowering in this group of cultivars.

RI increased and MDA decreased during the first $6 \mathrm{~d}$ of temperature treatments for ' $\mathrm{Kaa}$ Luoh-Lii' and 'Repulse' cultivars (Fig. 4), suggesting the plants adapted to the new environmental changes. From Day 6 to 27, the response of leaf RI to growing temperature differed between cultivars. Differential heat acclimation was reported for kentucky bluegrass (Poa pratensis L.) (Liu et al., 2008), 'Barlexas' tall fescue (Festuca arundinacea Schreb.), and 'Accent' perennial ryegrass (Lolium perenne L.) under heat stress (Xu et al., 2006). High temperature at $30 / 25^{\circ} \mathrm{C}$ for $27 \mathrm{~d}$ resulted in RI close to the value at Day 0 and did not alter MDA content in the heat-tolerant 'Kaa Luoh-Lii' (Figs. 4A and 4C), possibly as a result of adjustment of membrane structure and/or function under heat conditions (Xu et al., 2006). For the heat-intolerant 'Repulse', the $30 / 25{ }^{\circ} \mathrm{C}$ treatment for $27 \mathrm{~d}$ reduced leaf RI, but the reduced value was still higher than that at Day 0 (Fig. 4B). Leaf MDA content of 'Repulse' was higher at $30 / 25$ than at $20 / 15^{\circ} \mathrm{C}$ (Fig. 4D), indicating a higher membrane lipid peroxidation under heat (Halliwell and Gutteridge, 1989). MDA increased after the peak time of RI (Fig. 4), suggesting that MDA is a result of temperature-induced membrane damage and not the cause. Differences in MDA recovery occurred as a result of differences in temperature and cultivar. MDA recovery was faster at high temperatures because enzymatic-based membrane repair mechanisms would work faster. The heat-tolerant 'Kaa Luoh-Lii' might have better repair capabilities and thus recovered its MDA faster at 
$30 / 25^{\circ} \mathrm{C}$. This may partially explain why this cultivar grows and flowers better than heat-intolerant cultivars at higher temperatures. MDA acts as a biomarker because 1) as damaged membranes are repaired, MDA increases; 2) the more damage was done in heat-sensitive cultivars, the higher the MDA levels; and 3 ) heat-sensitive cultivars do not completely recover in the heat and, therefore, need continuous damage repair and show continuous MDA increase.

\section{Literature Cited}

Anderson, N.O. and P.D. Ascher. 2001. Selection of day-neutral, heatdelay-insensitive Dendranthema $\times$ grandiflora genotypes. J. Amer. Soc. Hort. Sci. 126:710-721.

Cathey, H.M. 1957. Chrysanthemum temperature study. F. The effect of temperature upon the critical photoperiod necessary for the initiation and development of flower of Chrysanthemum morifolium. J. Amer. Soc. Hort. Sci. 69:485-491.

Chen, H.H., Z.Y. Shen, and P.H. Li. 1982. Adaptability of crop plants to high temperature stress. Crop Sci. 22:719-725.

Cockshull, K.E. 1979. Effect of irradiance and temperature on flowering of Chrysanthemum morifolium Ramat. in continuous light. Ann. Bot. (Lond.) 44:451-460.

De Jong, J. 1989. The flowering of Chrysanthemum morifolium seedlings and cuttings in relation to seasonal fluctuation in light. Scientia Hort. 41:117-124.

Erwin, J.E., R.D. Heins, R.D. Berghage, and B. Kovanda. 1990. Temperature affects Schlumbergera truncate 'Madisto' flower initiation. Acta Hort. 272:97-101.

Fokar, M., H.T. Nguyen, and A. Blum. 1998. Heat tolerance in spring wheat. I. Estimating cellular thermotolerance and its heritability. Euphytica 104:1-8.

Halliwell, B. and J.M.C. Gutteridge. 1989. Free radicals in biology and medicine. Clarendon Press, Oxford, UK.

Heath, R.L. and L. Packer. 1968. Photoperoxidation in isolated chloroplasts. I. Kinetics and stoichiometry of fatty acid peroxidation. Arch. Biochem. Biophys. 125:189-198.

Inaba, M. and P.G. Crandall. 1988. Electrolyte leakage as an indicator of high-temperature injury to harvested mature green tomatoes. J. Amer. Soc. Hort. Sci. 113:96-99.

Ingram, D.L. and D.W. Buchanan. 1984. Lethal high temperatures for roots of three citrus root-stocks. J. Amer. Soc. Hort. Sci. 109:189193.

Ismail, A.M. and A.E. Hall. 1999. Reproductive-stage heat tolerance, leaf membrane thermostability and plant morphology in cowpea. Crop Sci. 39:1762-1768.

Karlsson, M.G., R.D. Heins, J.E. Erwin, and R.D. Berghage. 1989. Development rate during four phases of chrysanthemum growth as determined by preceding and prevailing temperatures. J. Amer. Soc. Hort. Sci. 114:234-240.
Lester, G.E. 1985. Leaf cell membrane thermostabilities of Cucumis melo. J. Amer. Soc. Hort. Sci. 110:506-509.

Liu, J., X. Xie, J. Du, J. Sun, and X. Bai. 2008. Effects of simultaneous drought and heat stress on kentucky bluegrass. Scientia Hort. 115:190-195.

Martineau, J.R., J.E. Specht, J.H. Williams, and C.Y. Sullivan. 1979. Temperature tolerance in soybeans I. Evaluation of a technique for assessing cellular membrane thermostability. Crop Sci. 19:75-78.

Saadalla, M.M., J.S. Quick, and J.F. Shanahan. 1990. Heat tolerance in winter wheat: II. Membrane thermostability and field performance. Crop Sci. 30:1248-1251.

Senthil-Kumar, M., G. Kumar, V. Srikanthbabu, and M. Udayakumar. 2007. Assessment of variability in acquired thermotolerance: Potential option to study genotypic response and the relevance of stress genes. J. Plant Physiol. 164:111-125.

Senthil-Kumar, M., V. Srikanthbabu, B. Mohan Raju, G. Kumar, N. Shivaprakash, and M. Udayakumar. 2003. Screening of inbred lines to develop a thermotolerant sunflower hybrid using the temperature induction response (TIR) technique: A novel approach by exploiting residual variability. J. Expt. Bot. 54:2569-2578.

Shibata, M. and J. Kawata. 1987. The introduction of heat tolerance for flowering from Japanese summer-flowering chrysanthemums into year-round chrysanthemums. Acta Hort. 197:77-81.

Sullivan, C.Y. 1972. Mechanisms of heat and drought resistance in grain sorghum and methods of measurement, p. 247-264. In: Rao, N.G.P. and L.R. House (eds.). Sorghum in the seventies. Oxford \& IBH Publishing, New Delhi, India.

Sullivan, C.Y. and W.M. Ross. 1979. Selecting for drought and heat resistance in grain sorghum, p. 263-281. In: Mussell, H. and R.C. Staples (eds.). Stress physiology in crop plants. Wiley, New York, NY. Warner, R.M. and J.E. Erwin. 2006. Prolonged high-temperature exposure differentially reduces growth and flowering of 12 Viola ×wittrockiana Gams. cvs. Scientia Hort. 108:295-302.

Whealy, C.A., T.A. Nell, and J.E. Barrent. 1987. High temperature effects on growth and floral development of chrysanthemum. J. Amer. Soc. Hort. Sci. 112:464-468.

Wu, M.T. and S.J. Wallner. 1983. Heat stress responses in cultured plant cells: Development and comparison of viability tests. Plant Physiol. 72:817-820.

Xu, S., J. Li, X. Zhang, H. Wei, and L. Cui. 2006. Effects of heat acclimation pretreatment on changes of membrane lipid peroxidation, antioxidant metabolites, and ultrastructure of chloroplasts in two cool-season turfgrass species under heat stress. Environ. Expt. Bot. 56:274-285.

Yeh, D.M. and P.Y. Hsu. 2004. Heat tolerance in english ivy as measured by an electrolyte leakage technique. J. Hort. Sci. Biotechnol. 79:298-302.

Yeh, D.M. and H.F. Lin. 2003. Thermostability of cell membrane as a measure of heat tolerance and relationship to flowering delay in chrysanthemum. J. Amer. Soc. Hort. Sci. 128:656-660. 